\section{(A) Check for updates}

Cite this: Nanoscale, 2020, 12, 2626

\title{
Controlling protein interactions in blood for effective liver immunosuppressive therapy by silica nanocapsules $\uparrow$
}

\author{
Shuai Jiang, (D) a Domenik Prozeller, (D) a Jorge Pereira, ${ }^{a}$ Johanna Simon, ${ }^{a, b}$ \\ Shen Han, ${ }^{a}$ Sebastian Wirsching, ${ }^{c}$ Michael Fichter, ${ }^{c}$ Milagro Mottola, (D) ${ }^{a}$ \\ Ingo Lieberwirth, (D) a Svenja Morsbach, (D) a Volker Mailänder, (D) a,b \\ Stephan Gehring, ${ }^{c}$ Daniel Crespy (D) *a,d and Katharina Landfester (D)*a
}

\begin{abstract}
Immunosuppression with glucocorticoids is a common treatment for autoimmune liver diseases and after liver transplant, which is however associated with severe side-effects. Targeted delivery of glucocorticoids to inflammatory cells, e.g. liver macrophages and Kupffer cells, is a promising approach for minimizing side effects. Herein, we prepare core-shell silica nanocapsules $\left(\mathrm{SiO}_{2} \mathrm{NCs}\right)$ via a sol-gel process confined in nanodroplets for targeted delivery of dexamethasone (DXM) for liver immunosuppressive therapy. DXM with concentrations up to $100 \mathrm{mg} \mathrm{mL}^{-1}$ in olive oil are encapsulated while encapsulation efficiency remains over $95 \%$ after 15 days. Internalization of NCs by non-parenchymal murine liver cells significantly reduces the release of inflammatory cytokines, indicating an effective suppression of inflammatory response of liver macrophages. Fluorescent and magnetic labeling of the NCs allows for monitoring their intracellular trafficking and biodegradation. Controlled interaction with blood proteins and good colloidal stability in blood plasma are achieved via PEGylation of the NCs. Specific proteins responsible for stealth effect, such as apolipoprotein A-I, apolipoprotein A-IV, and clusterin, are present in large amounts on the PEGylated NCs. In vivo biodistribution investigations prove an efficient accumulation of NCs in the liver, underlining the suitability of the $\mathrm{SiO}_{2} \mathrm{NCs}$ as a dexamethasone carrier for treating inflammatory liver diseases.
\end{abstract}

Received 20th November 2019, Accepted 30th December 2019 DOI: 10.1039/c9nr09879h rsc.li/nanoscale

\section{Introduction}

Liver diseases such as autoimmune hepatitis, primary biliary cirrhosis, and primary sclerosing cholangitis are induced by overwhelming inflammatory immune responses. Immunosuppression with glucocorticoids is a common treatment option for autoimmune liver diseases and after liver transplant, even for pediatric patients. ${ }^{1}$ However, glucocorticoids do not act specifically on liver cells and their long-term systemic administration is associated with severe side effects

\footnotetext{
${ }^{a}$ Max Planck Institute for Polymer Research, Ackermannweg 10, 55128 Mainz, Germany.E-mail: landfester@mpip-mainz.mpg.de, daniel.crespy@vistec.ac.th ${ }^{b}$ Dermatology Clinic, University Medical Center of the Johannes GutenbergUniversity, Langenbeckstr. 1, 55131 Mainz, Germany

${ }^{c}$ Children's Hospital, University Medical Center of the Johannes-Gutenberg University, Mainz, Germany

${ }^{d}$ Department of Materials Science and Engineering, School of Molecular Science and Engineering, Vidyasirimedhi Institute of Science and Technology (VISTEC), Rayong 21210, Thailand

$\dagger$ Electronic supplementary information (ESI) available. See DOI: 10.1039/ c9nr09879h
}

such as osteoporosis, hypertension, hyperglycemia, adrenal insufficiency, myopathy, metabolic disturbances, and stomach and intestinal bleeding due to ulcers. ${ }^{2-4}$ Targeted delivery of glucocorticoids to inflammatory liver cells, e.g. Kupffer cells and macrophages, represents hence a promising approach for increasing drug bioavailability in targeted tissue and organs and reducing systemic adverse effects. ${ }^{5-9}$

Dexamethasone (DXM) is a very common glucocorticoid drug. ${ }^{5}$ Although it is considered as one of the safest glucocorticoids, a broad spectrum of side effects have been still observed; mostly due to its hydrophobicity. ${ }^{5}$ Sodium salt of DXM was recommended as hydrophilic alternative of the drug, but its use can lead to sodium overdosing. ${ }^{5}$ Water-soluble polymers and nanoparticles have been used as drug carriers for increasing the solubility of hydrophobic drugs. ${ }^{10}$ Because large quantities of nanoparticles translocate to the liver by passive targeting upon parenteral administration, ${ }^{11-13}$ nanocarriermediated drug delivery represents a promising strategy for combatting liver diseases. ${ }^{14}$

There are two main strategies for the controlled delivery of DXM. In the first approach, DXM molecules were conjugated 
to hydrophilic polymers ${ }^{15-22}$ and nanoparticles ${ }^{23,24}$ via reactions with ketone 16-20,22,25,26 $^{\text {or hydroxyl }}$ 20,21,23,27 $_{\text {groups of }}$ DXM. The formed hydrazone or ester linkages allowed a specific release of DXM in response to acidic local environment in inflammatory tissues. This approach relies on the modification of polymers and/or the parent drug, and the linker chemistry, and therefore multi-step synthesis and purifications are usually required. Alternatively, DXM compounds can be directly loaded in nanoparticles. A variety of nanoparticles prepared from biodegradable polymers such as PLGA, ${ }^{28-37}$ PLLA $^{38}$ PCL,${ }^{38}$ cellulose, ${ }^{39}$ cyclodextrin, ${ }^{40}$ chitosan, ${ }^{41}$ polyglutamic acid, ${ }^{42}$ or $\operatorname{lipids}^{43}$ and inorganic materials, ${ }^{10,44}$ as well as polymer micelles, ${ }^{45}$ liposomes, ${ }^{46-49}$ and carbon nanotubes ${ }^{50}$ have been used to transport DXM. Entrapment of DXM in nanoparticles led usually to a prolonged and sustained release of DXM..$^{10,30-40,44,50}$ Nevertheless, premature release of DXM before reaching the targeting tissues is still an issue. In order to minimize side effects due to leakage of drug and increase its bioavailability, an efficient encapsulation and a selective release drug delivery system are needed.

Furthermore, most of the DXM nano-formulations were developed for topical therapies, e.g. the treatment of ophthalmic, ${ }^{30,42,45,51}$ dermal, $^{10,39}$ respiratory, ${ }^{32,52}$ bowel, ${ }^{43,53}$ brain, ${ }^{36,41}$ and joint diseases ${ }^{18,24,28,29,54-56}$ by local administration. In this case, the nanoencapsulation is mainly used for increasing local concentration of drugs and controlling their release kinetics. However, intravenous administration of nanocarriers is usually applied for treating liver diseases. ${ }^{9,13,57}$ Once the nanocarriers enter into the blood stream, various blood components such as proteins and lipids rapidly interact with nanocarriers and cover their surface. ${ }^{58,59}$ This biomolecular corona has been shown to be a key parameter that mediates in vivo behavior of nanocarriers. ${ }^{60}$ Therefore, a systematic study on the interaction of DXM-nanocarriers with blood proteins and the resulting colloidal stability and biodistribution of nanocarriers are essential for assessing the effectivity of nanocarrier-mediated targeted delivery.

In this study, we developed multifunctional core-shell silica nanocapsules ( $\left.\mathrm{SiO}_{2} \mathrm{NCs}\right)$ via an interfacially confined sol-gel process for targeted delivery of DXM for liver immunosuppressive therapy (Fig. 1). Silica nanomaterials show good biocompatibility, tunable porosity, and ease of surface modification. Therefore, they have been widely studied for biological applications. ${ }^{61}$ The core-shell structure of the NCs enables high encapsulation efficiency of DXM at high concentrations and an intracellularly selective release upon biodegradation of the shell. Controlled interactions with blood proteins and good colloidal stability of the NCs in blood plasma were achieved by PEGylation of the NCs, which are prerequisites for an effective in vivo targeted delivery.

\section{Results and discussion}

\section{Encapsulation of DXM in $\mathrm{SiO}_{2} \mathrm{NCs}$}

DXM was encapsulated in the liquid core of the $\mathrm{SiO}_{2} \mathrm{NCs}$. Hydrophobic DXM was first dissolved in olive oil at concentrations from 1 to $100 \mathrm{mg} \mathrm{mL} \mathrm{m}^{-1}$. The olive oil solution was mixed with hexadecane, functional silica precursors, and iron oxide nanoparticles $\left(\mathrm{Fe}_{3} \mathrm{O}_{4} \mathrm{NPs}\right)$ to form the dispersed phase. The hydrophobic mixtures were dispersed in an aqueous solution of the cationic surfactant cetyltrimethylammonium chloride (CTMA-Cl). The CTMA-Cl stabilized the miniemulsion droplets against coalescence and confined the condensation of silica precursors at the oil/water interface via a cooperative

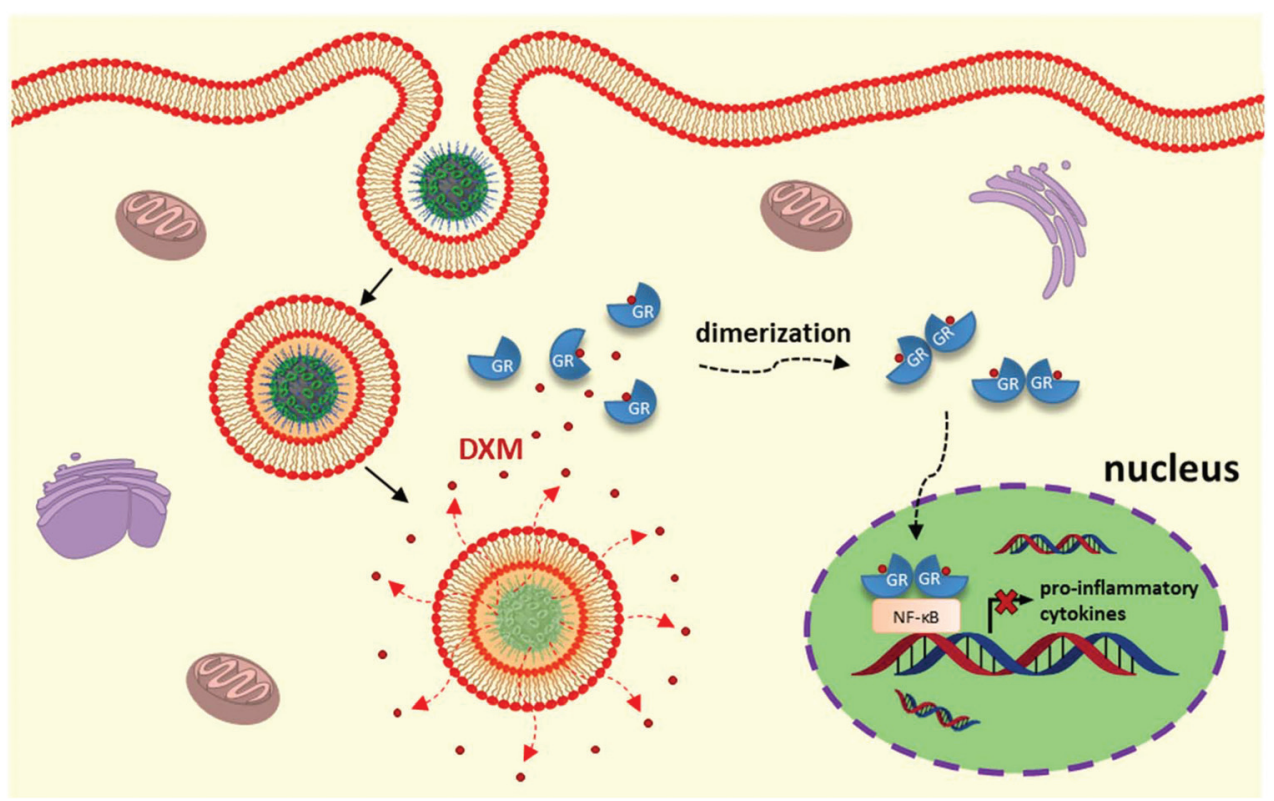

Fig. 1 Schematic illustration of nanocarrier-mediated targeted delivery of dexamethasone for liver immunosuppressive therapy. 


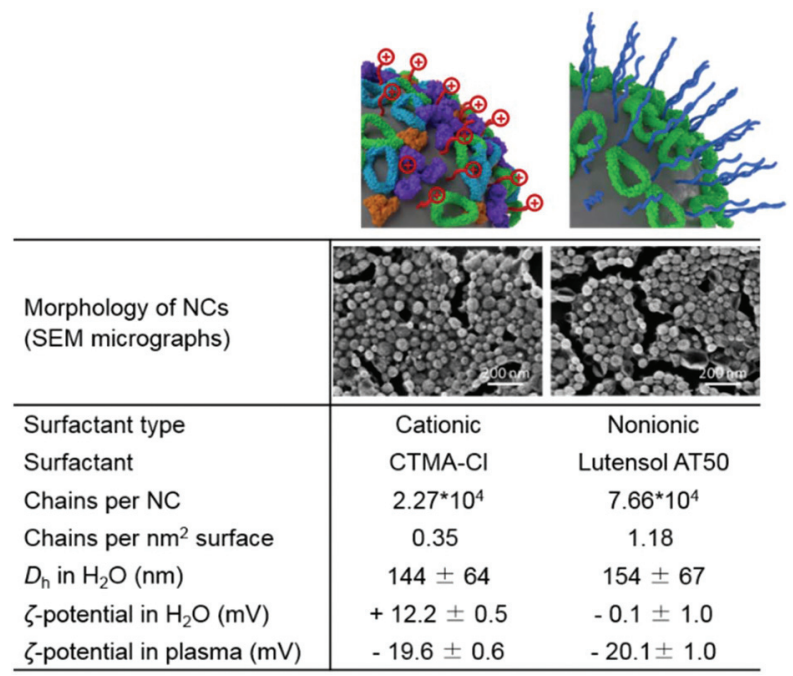

Fig. 2 Colloidal characteristics of the $\mathrm{SiO}_{2} \mathrm{NCs}$. SEM micrographs of the NCs, average number and surface density of CTMA-Cl and Lutensol AT50 surfactant molecules, hydrodynamic diameter $D_{\mathrm{h}}$, and zeta potential of the $\mathrm{SiO}_{2} \mathrm{NCs}$ in water and plasma.

assembly between negatively charged silica species with the cationic surfactant. ${ }^{62}$ A silica shell was therefore formed around nanodroplets containing DXM and $\mathrm{Fe}_{3} \mathrm{O}_{4} \mathrm{NPs}^{63}$

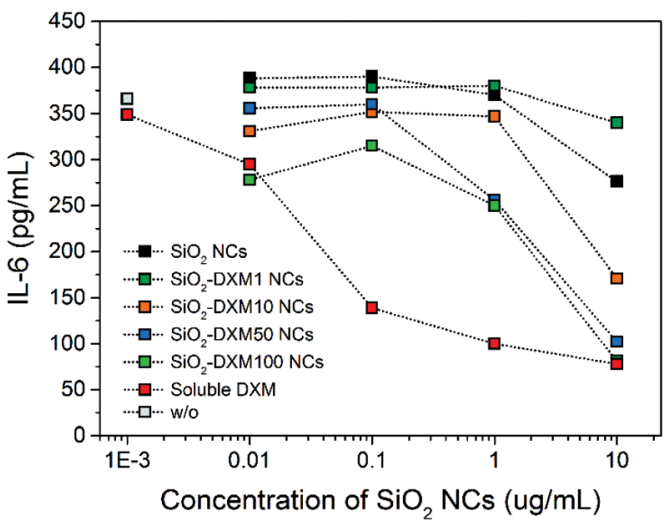

Fig. 4 Evolution of IL-6 secretion in non-parenchymal liver cells after stimulation with $2.5 \mu \mathrm{g} \mathrm{mL}{ }^{-1}$ LPS treated with $\mathrm{SiO}_{2} \mathrm{NCs}$ containing various concentrations of DXM. All conditions were compared to a positive control (LPS stimulated) and significance was given with $p<0.001$ (*) (two-way ANOVA with Dunnett's multiple comparison test).

Simultaneously, fluorescently modified silica precursors were copolymerized in the silica network. Therefore, drug encapsulation and fluorescent and magnetic labeling of NCs were carried out in one step.

$\mathrm{SiO}_{2}$ NCs with an average hydrodynamic diameter of $144 \pm$ $64 \mathrm{~nm}$ and $\zeta$-potential of $+12.2 \pm 0.5 \mathrm{mV}$ were obtained. Core-

(a)
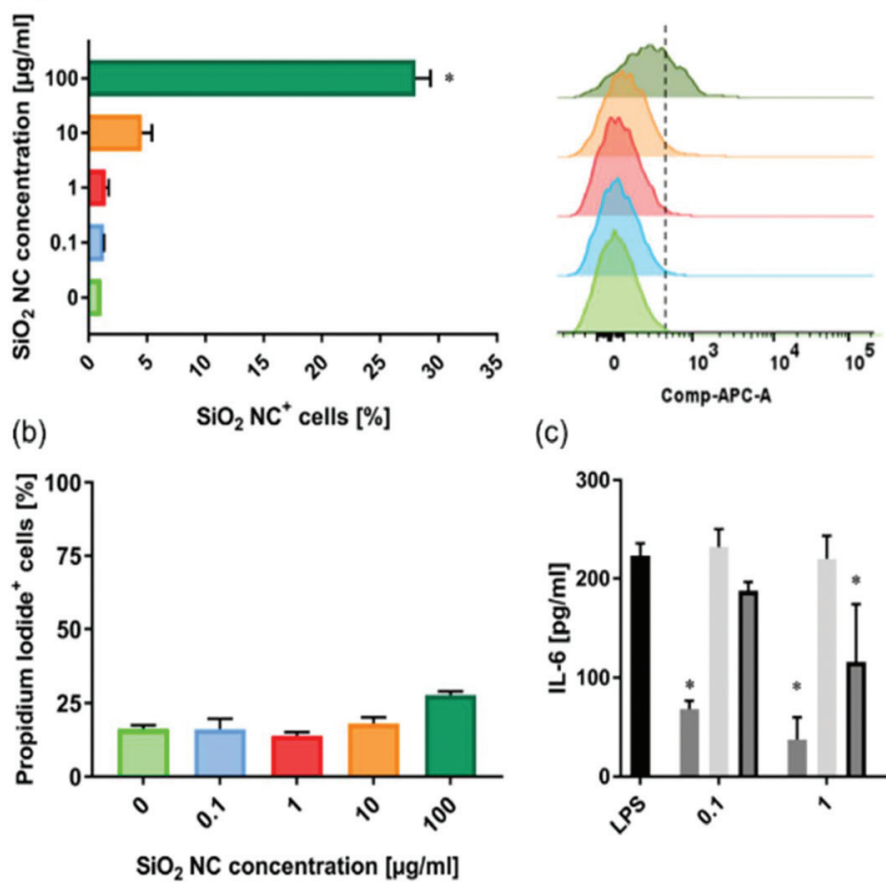

(c)
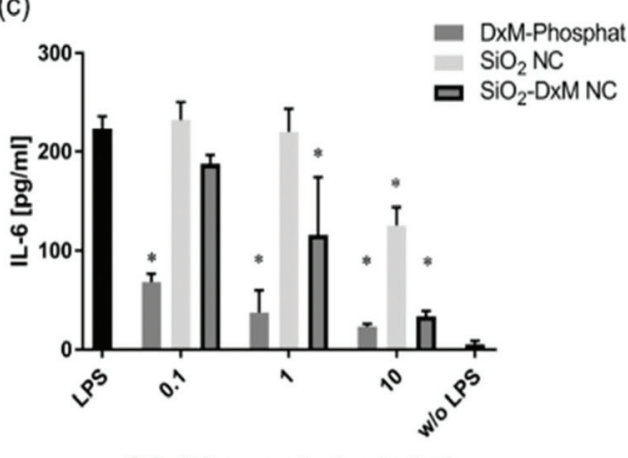

$\mathrm{SiO}_{2} \mathrm{NC}$ concentration $[\mu \mathrm{g} / \mathrm{ml}]$

Fig. 3 (a) Uptake of $\mathrm{SiO}_{2} \mathrm{NCs}$ with increasing concentrations by non-parenchymal liver cells in vitro evaluated by flow cytometry. All conditions were compared to the negative control (without $\mathrm{SiO}_{2} \mathrm{NCs}$ ) and significance was given with $p<0.001$ (*) (one-way ANOVA). (b) Cytotoxicity of SiO 2 $\mathrm{NCs}$ measured by evaluating the number of propidium iodide positive cells by flow cytometry. (c) Effect of $\mathrm{SiO}_{2} \mathrm{NCs}$ with increasing concentrations on IL-6 secretion of NPCs after stimulation with $2.5 \mu \mathrm{g} \mathrm{mL} \mathrm{m}^{-1} \mathrm{LPS}$. All conditions were compared to the positive control (LPS stimulated) and significance was given with $p<0.001{ }^{*}$ ) (two-way ANOVA with Dunnett's multiple comparison test). Data represent mean \pm SD $(n=3)$. 
shell morphology of the $\mathrm{SiO}_{2}$ NCs was identified by SEM and TEM (Fig. 2), indicating a confined condensation of alkoxysilanes around miniemulsion droplets. The average shell thickness was determined to be $5 \pm 2 \mathrm{~nm}$ from TEM micrographs. Surface of the NCs was PEGylated by replacing the CTMA-Cl with a PEG-based nonionic surfactant Lutensol AT50 by dialysis. According to HPLC measurements performed to measure the concentration of CTMA-Cl in the dialysis media, 90\% CTMA-Cl was removed. Remarkably, nanocapsules dispersions were stable during the surfactant-exchange process. Size of NCs increased slightly from $144 \pm 64 \mathrm{~nm}$ for CTMA-Cl stabilized NCs to $154 \pm 67 \mathrm{~nm}$ for Lutensol AT50 stabilized NCs. The surface charge of NCs turned from positive $(+12.2 \pm 0.5 \mathrm{mV})$ to neutral $(-0.1 \pm 1.0 \mathrm{mV})$ after PEGylation. The slightly negative charge was due to the dissociation of silanol groups at experi- mental $\mathrm{pH}(4-5)$, which is above the isoelectric point of silica $(\sim \mathrm{pH} 2-3) .{ }^{62}$ Encapsulation efficiency of DXM in the PEGylated NCs was subsequently investigated by dialyzing the nanocapsules dispersions. Less than 5\% of DXM was released in 15 days (Fig. S1†), indicating a minimal leakage which is beneficial for avoiding side effects from diffused free corticosteroids.

\section{Immunosuppression with $\mathrm{SiO}_{2}$-DXM NCs}

Murine non-parenchymal liver cells were incubated with the $\mathrm{SiO}_{2} \mathrm{NCs}$ at various concentrations for $24 \mathrm{~h}$. Cellular uptake of NCs was quantified by using flow cytometry. A concentrationdependent cellular uptake of NCs was observed (Fig. 3a). The uptake increased from $\sim 5 \%$ to $28 \%$ as the concentration of NCs increased from 10 to $100 \mu \mathrm{g} \mathrm{mL}^{-1}$ in cell culture. The cells

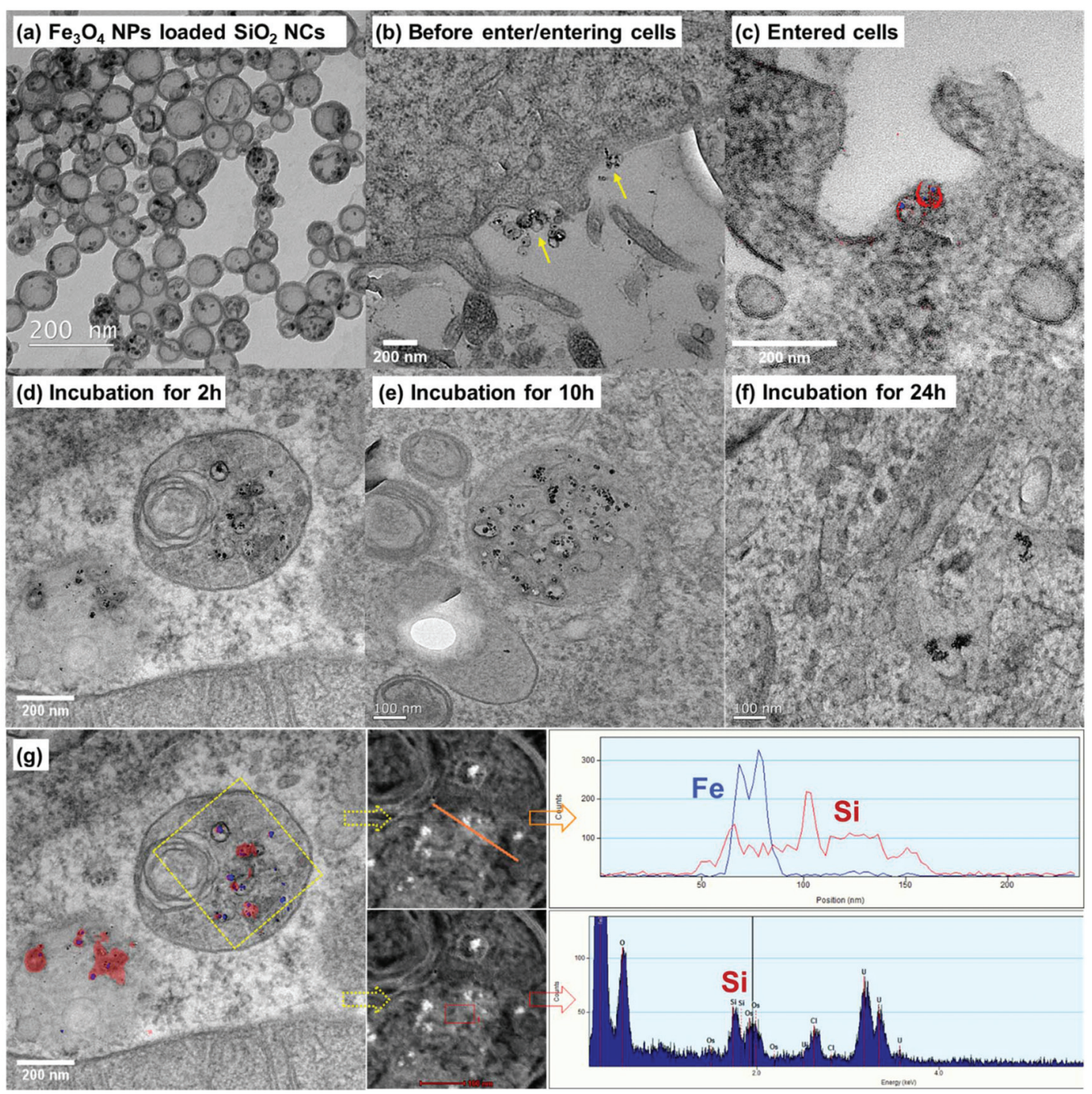

Fig. 5 Cellular uptake and localization of iron oxide labeled $\mathrm{SiO}_{2} \mathrm{NCs}$ in HeLa cells based on TEM and elemental mapping techniques. TEM micrographs of (a) $\mathrm{Fe}_{3} \mathrm{O}_{4} \mathrm{NPs}$ labeled $\mathrm{SiO}_{2} \mathrm{NCs}$. (b) NCs that are entering cell membrane shown by yellow arrows. (c) NCs internalized in cell. (d-f) Localization of NCs in intracellular environments after incubation for 2, 10, and $24 \mathrm{~h}$. (g) Blue color represents signal of iron and red color represents signal of silicon. 
were stained with propidium iodide for quantifying the population of dead cells. The $\mathrm{SiO}_{2}$ NCs showed low effect on cell viability especially at low concentrations, which is in line with previous reports from other groups. ${ }^{64,65}$ Incubation with $100 \mu \mathrm{g} \mathrm{mL} \mathrm{m}^{-1}$ of NCs led to a slight increase of dead cells from $\sim 17 \%$ to $28 \%$ (Fig. $3 \mathrm{~b}$ ).

ELISA assays were performed to study the effect of encapsulated DXM on interleukin-6 (IL-6) secretion of lipopolysaccharide (LPS) stimulated non-parenchymal liver cells after $24 \mathrm{~h}$ incubation in vitro. Treatment of the cells with $\mathrm{SiO}_{2}$-DXM NCs led to a dose-dependent decrease of IL-6 secretion (Fig. 3c). Incubation with $10 \mu \mathrm{g} \mathrm{mL}^{-1} \mathrm{SiO}_{2}$-DXM NCs generated a tenfold reduction of secreted IL-6, showing an effect comparable to the treatment with water-soluble DXM phosphate. One advantage of nanocapsules over nanoparticle carriers is their core-shell structure that offers a high encapsulation capacity. DXM with concentrations ranging from 1 to $100 \mathrm{mg} \mathrm{mL}^{-1}$ in olive oil was encapsulated as liquid core in $\mathrm{SiO}_{2} \mathrm{NCs}$, denoted as $\mathrm{SiO}_{2}$-DXM1(-100) NCs in Table S1. $\dagger$ Average $D_{\mathrm{h}}$ of the $\mathrm{SiO}_{2}$ DXM NCs was around 130-180 nm. Encapsulation efficiency of DXM in NCs increased to $\sim 97 \%$ at loading concentration of $100 \mathrm{mg} \mathrm{mL} \mathrm{m}^{-1}$ in the core oil. As shown in Fig. 4, the suppression efficiency of $\mathrm{SiO}_{2}$-DXM NCs for IL-6 secretion was enhanced significantly by increasing DXM loading content. The suppression effects of $\mathrm{SiO}_{2}$-DXM NCs at internal loading concentration of 50 and $100 \mathrm{mg} \mathrm{mL} \mathrm{mL}^{-1}$ were comparable to the water-soluble DXM phosphate at a concentration of 10 $\mu \mathrm{g} \mathrm{mL}^{-1}$.

\section{Cellular uptake behavior and intracellular trafficking of $\mathrm{SiO}_{2}$ NCs}

Understanding cellular uptake, intra-, and intercellular trafficking mechanisms of nanocarriers is critical for designing efficient and safe nanomedicines. ${ }^{66}$ We studied the cellular uptake behavior and intracellular trafficking of the $\mathrm{SiO}_{2} \mathrm{NCs}$ by TEM. However, because the $\mathrm{SiO}_{2}$ NCs have a core-shell structure and size of $\sim 100 \mathrm{~nm}$, they are difficult to distinguish from cellular organelles on TEM micrographs. To overcome this issue, we labeled the $\mathrm{SiO}_{2}$ NCs with $\mathrm{Fe}_{3} \mathrm{O}_{4}$ NPs as contrast agent. Labeling of iron oxide also allowed the localization of NCs by monitoring elemental distribution of silicon and iron. As shown in Fig. 5a, the $\mathrm{Fe}_{3} \mathrm{O}_{4}$ NPs with diameter of $\sim 8 \mathrm{~nm}$ were encapsulated in the inner core of NCs. To prove the efficient loading of $\mathrm{Fe}_{3} \mathrm{O}_{4}$ NPs in NCs, gradient centrifugation technique was applied. No free $\mathrm{Fe}_{3} \mathrm{O}_{4}$ NPs were separated from the $\mathrm{SiO}_{2}$ NCs present in the upper phase (Fig. S2 $\dagger$ ), indicating a high encapsulation efficiency of the NPs. By encapsulating $\mathrm{Fe}_{3} \mathrm{O}_{4}$ NPs as contrast agent, $\mathrm{SiO}_{2}$ NCs were clearly distinguished from cellular organelles (Fig. 5b-e). Combined with elemental mapping of silicon and iron obtained by electron energy loss spectroscopy (EELS) and energy dispersive X-ray spectroscopy (EDS), cellular uptake of the $\mathrm{SiO}_{2} \mathrm{NCs}$ and their localization in intracellular environment were successfully identified (Fig. 5g). Intracellular trafficking of the NCs was studied at different incubation times (Fig. 5c-f). Iron oxide labeled NCs were found in multivesicular bodies after 2 hours incubation (Fig. 5d). After incubating the cells with magnetic NCs for 10 and $24 \mathrm{~h}$, some free $\mathrm{Fe}_{3} \mathrm{O}_{4}$ NPs, without surrounding silica shell, were observed (Fig. 5e and $\mathrm{f}$ ). This observation indicates a plausible intracellular degradation of the ultrathin silica shell $(\sim 5 \mathrm{~nm})$, which is consistent with previous findings from other groups. Chen et al. found that the degradation of surfactant-extracted MCM-41-type mesoporous silica nanoparticles exhibited a very fast initial degradation within $2 \mathrm{~h}$ in simulated body fluid. ${ }^{67}$ The incomplete -Si-O- tetrahedral network in the nanoparticles, containing plenty of $\mathrm{Si}-\mathrm{R}$ and $\mathrm{Si}-\mathrm{OH}$ groups, facilitated their easy degradation. Bein et al. found that small particle size $(50-70 \mathrm{~nm})$ with a low conden-

a)
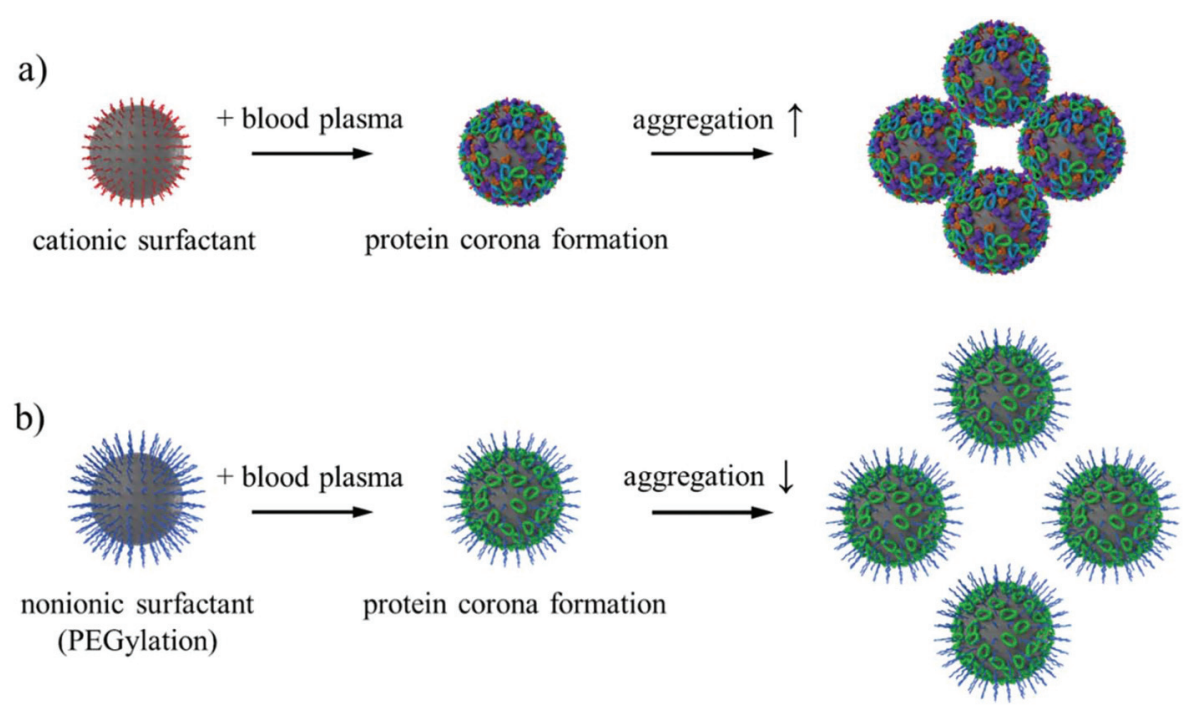

Fig. 6 Schematic illustration of the aggregation state of $\mathrm{SiO}_{2} \mathrm{NCs}$ stabilized with cationic surfactant CTMA-Cl and nonionic surfactant Lutensol AT50. 
sation degree and a highly mesoporous texture (pore size 3-4 $\mathrm{nm}$ ), and high surface area accelerated the degradation reactions. ${ }^{68}$ In our case, the $\mathrm{SiO}_{2}$ NCs showed also a low condensation degree, as shown by the $\mathrm{Q}_{2}$ signal of $1 \%, \mathrm{Q}_{3}$ signal of $43 \%$, and $\mathrm{Q}_{4}$ signal of $56 \%$ determined by ${ }^{29} \mathrm{Si}$ MAS NMR spectroscopy. The combination of the presence of free $\mathrm{Si}-\mathrm{R}$ and $\mathrm{Si}-\mathrm{OH}$ groups with the thin shell and a pore size of $\sim 3-6 \mathrm{~nm}$ is therefore likely to facilitate the intracellular degradation of the $\mathrm{SiO}_{2} \mathrm{NCs}$.

\section{Protein interaction and colloidal stability of $\mathrm{SiO}_{2} \mathrm{NCs}$ in blood plasma}

For successful in vivo application of nanocarriers as drug delivery vehicles, the nanocarriers need to remain colloidally stable in blood plasma. With dynamic light scattering, it is possible to directly monitor the aggregation state of nanocarriers in concentrated blood plasma. ${ }^{69,70}$ This method is suitable for screening the behavior of nanocarriers in blood plasma prior to in vivo investigations. The $\mathrm{SiO}_{2} \mathrm{NCs}$ stabilized by cationic surfactant CTMA-Cl formed macroscopic aggregates in concentrated plasma. However, aggregation formation was significantly reduced after PEGylation of the NCs with the PEG-based nonionic surfactant Lutensol AT50 (Fig. 6). Surface charge of the NCs was reduced from $+12 \mathrm{mV}$ to $\sim 0 \mathrm{mV}$ due to the removal of cationic surfactant (Fig. 2). With increased density of PEG chains on the surface, the $\mathrm{SiO}_{2}$ NCs became more stable in PBS and in blood plasma (Fig. S3†). Especially, going from 0.64 to 0.96 PEG chains per $\mathrm{nm}^{2}$ resulted in a major stability improvement, suggesting a certain threshold of required surface PEG density. While some aggregates of $\mathrm{SiO}_{2}$ NCs in blood plasma could still be observed after PEGylation, the intensity contribution factor of these larger species suggest that their actual concentration is very low compared to stable NCs (Fig. S3b $\dagger$ ). The exemplary autocorrelation functions of the corresponding measured samples are given in Fig. S4.†

Furthermore, it has been recognized in recent years that various blood components such as proteins and lipids rapidly interact with the nanocarriers and cover their surface upon entering of the nanocarriers into blood plasma. ${ }^{58,59}$ This process, coined 'biomolecular corona formation', has been shown to be a key parameter that mediates in vivo behavior of nanocarriers. ${ }^{60}$ As widely described in literature, PEGylated nanocarriers have a prolonged blood circulation time caused

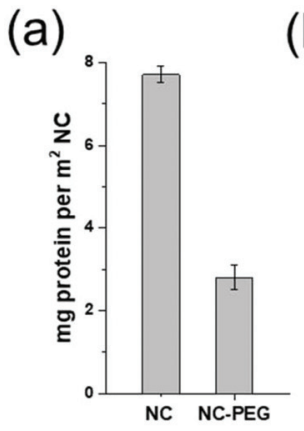

(b)

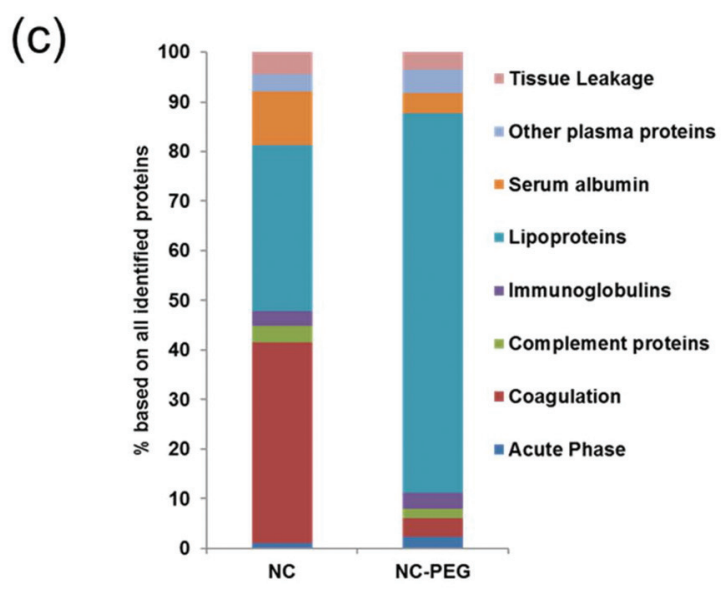

(d)

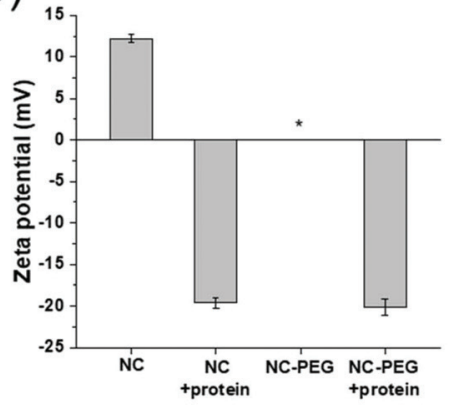
cathe

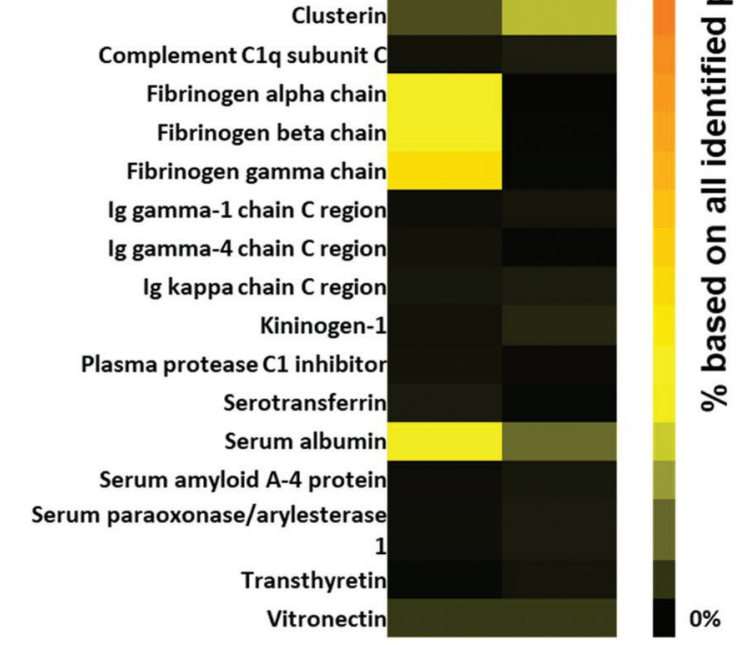

Fig. 7 Analysis of the protein corona. (a) Absolute amount of corona proteins on PEGylated and non-PEGylated $\mathrm{SiO}_{2} \mathrm{NCs}$ determined by Pierce Assay. (b) Zeta potential of $\mathrm{SiO}_{2} \mathrm{NC}$-PEG before or after incubation with blood plasma. (c) Isolated corona proteins identified by LC-MS. All proteins were categorized into eight different classes based on their biological function. (d) Heatmap displaying the most abundant proteins in the protein corona on $\mathrm{SiO}_{2} \mathrm{NCs}$ before and after PEGylation. Only the proteins contributing to at least $1 \%$ of the protein corona on one of the nanocapsules are shown. Relative values (\%) were calculated based on the absolute amount of each protein (fmol). A detailed list of all identified proteins is supplemented as Table S2.† 
by reduced protein adsorption, which subsequently induces a lower cellular interaction with phagocytic cells (referred to as 'stealth effect'). ${ }^{71,72}$ The PEGylated $\mathrm{SiO}_{2}$ NCs adsorbed a significantly lower amount of plasma proteins $(2.8 \pm 0.3 \mathrm{mg}$ per $\mathrm{m}^{2} \mathrm{NC}$ surface area) compared to non-PEGylated $\mathrm{SiO}_{2} \mathrm{NCs}$ $\left(7.7 \pm 0.2 \mathrm{mg}\right.$ per $\mathrm{m}^{2} \mathrm{NC}$ surface area; Fig. 7a). However, protein adsorption was not completely prevented, a phenomenon that was previously reported for PEGylated polystyrene nanoparticles. ${ }^{73,74}$ Through a detailed proteomic investigation, we were able to identify the key proteins that adsorbed onto the $\mathrm{SiO}_{2}$ NCs after incubation in blood plasma (Fig. 7c and d).

We found that there was a significant change in the protein pattern after PEGylation of $\mathrm{SiO}_{2}$ NCs. Indeed, there was an overall increased amount of lipoproteins making up $76.4 \%$ of the total protein corona content, which specifically adsorbed to PEGylated $\mathrm{SiO}_{2}$ NCs in comparison to non-PEGylated capsules (Fig. 7c). ${ }^{75}$ Especially, the relative amount of apolipoprotein A-I, apolipoprotein A-IV, and clusterin increased. Clusterin, also known as apolipoprotein $\mathrm{J}$, was identified as major component of various PEGylated nanocarriers and it was shown to display dysopsonic properties due to its ability to reduce interaction with phagocytic cells. ${ }^{74,76}$ Apolipoprotein A-I can substitute clusterin in this function. ${ }^{77-79}$ In contrast, non-PEGylated $\mathrm{SiO}_{2}$ NCs were surrounded by fibrinogen, which is a protein involved in blood coagulation and potentially mediates the aggregation of nanocapsules. ${ }^{80}$ In our case, the aggregation of CTMA-Cl stabilized NCs consequently most likely originated from the fibrinogen interactions due to their positively charged capsule surface.

The effect of protein corona on release profiles of drug from $\mathrm{Fe}_{3} \mathrm{O}_{4}$ NPs, polymer NCs, and commercial nanocarriers (Abraxane®, albumin-bound paclitaxel) was investigated. ${ }^{81}$ The protein corona was found to delay the release of drugs. The drug release profile of nanocarriers depended on their interaction with the protein corona, i.e. on the type and amount of associated proteins in the hard corona, and on the size/type of nanocarriers. The protein corona reduced the burst release effect for protein-conjugated drug and carriers with surface-loaded drug. However, drug release profiles of polymer NCs were only slightly influenced by the protein corona.

Next, we investigated the in vivo distribution of $\mathrm{SiO}_{2} \mathrm{NCs}$ after intravenous injection in mice. The $\mathrm{SiO}_{2} \mathrm{NCs}$ were covalently labeled with the NIR fluorophore Cy7.5 at various labeling densities $\left(\mathrm{SiO}_{2} \mathrm{NC}-\mathrm{Cy} 7.5, \mathrm{NC}-2 \times \mathrm{Cy} 7.5\right.$, and $\mathrm{NC}-4 \times$ Cy7.5) by coupling the amine-reactive molecular probe Cy7.5NHS with 3-aminopropyltriethoxysilane. Injected NCs were accumulated in the liver at $30 \mathrm{~min}$ after intravenous injection whereas no signal was detected in the other organs (Fig. 8a and b). Total radiant efficiency of accumulated NCs in isolated livers increased when the labeling density of fluorophores increased in the NCs (Fig. 8c). This enrichment of nanocapsules in the livers underlines the suitability of $\mathrm{SiO}_{2} \mathrm{NCs}$ as dexamethasone carrier for the treatment of inflammatory liver diseases such as alcoholic hepatitis, which are standardly treated with glucocorticoids. ${ }^{82}$
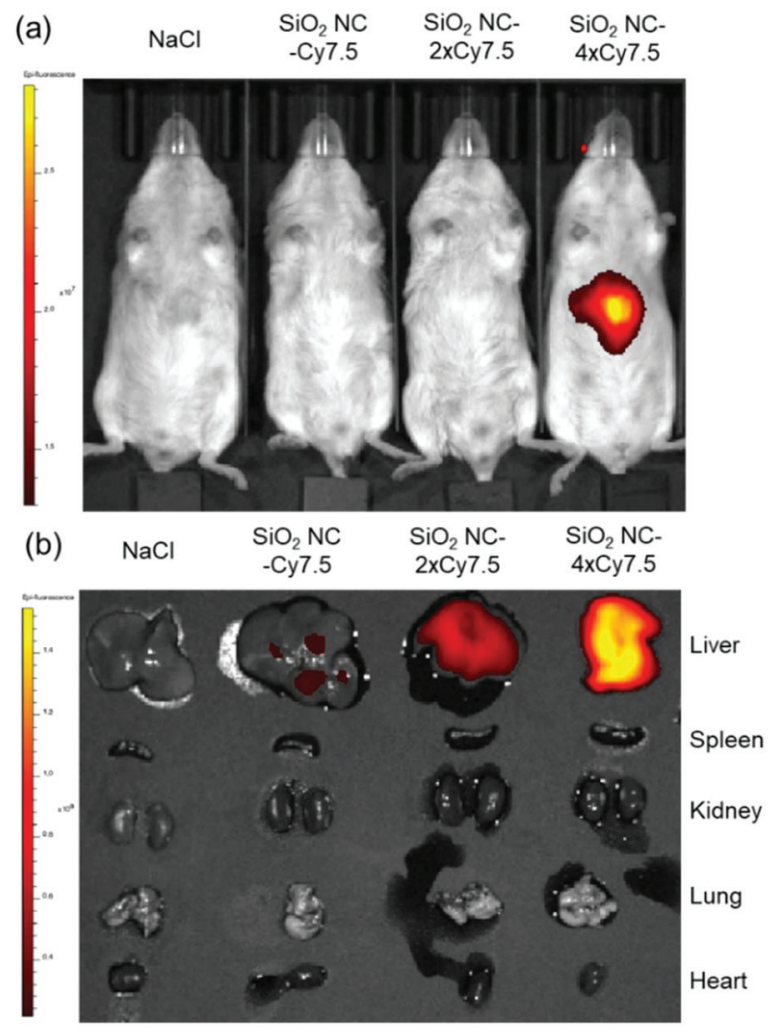

(c)

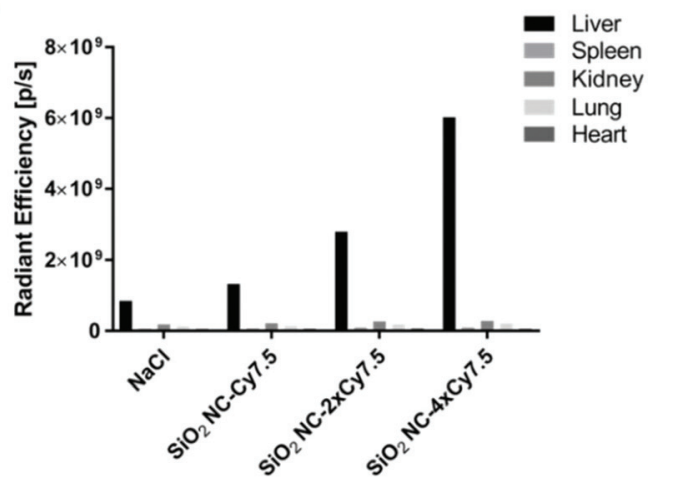

Fig. 8 IVIS imaging of in vivo distribution of $\mathrm{SiO}_{2} \mathrm{NCs}$ labeled with Cy7.5 observed at 30 min after intravenous injection in C57BL6/albino mice. (a) Epi-illumination image of mice. (b) Ex vivo imaging of separate organs. (c) Total radiant efficiencies of accumulated NCs in isolated organs. Data represent mean $(n=1)$.

\section{Conclusions}

We developed core-shell silica nanocapsules displaying efficient and targeted delivery of dexamethasone for liver immunosuppressive therapy. The oil core could dissolve DXM at concentrations up to $100 \mathrm{mg} \mathrm{mL}^{-1}$ while the encapsulation efficiency was kept over 95\% after 15 days. Therefore, side effects from premature leakage of DXM are expected to be significantly reduced. The $\mathrm{SiO}_{2}$-DXM NCs showed an effective suppression of inflammatory response of liver macrophages by reducing the secretion of inflammatory cytokines. Intracellular trafficking and degradation of NCs were investigated by label- 
ing them with fluorescent dyes and magnetic nanoparticles. By a simple PEGylation process, controlled interactions with blood proteins and good colloidal stability of NCs in blood plasma were achieved with an efficient accumulation in the liver. The efficient encapsulation, multimodal labeling, controlled protein interaction, colloidal stability in blood, and enrichment in the liver underline the suitability of the $\mathrm{SiO}_{2}$ NCs as glucocorticoids carrier for the treatment of inflammatory liver diseases.

\section{Experimental section}

\section{Materials}

Tetraethoxysilane (TEOS, Alfa Aesar, 98\%), 3-aminopropyltrimethoxysilane (APTES, Alfa Aesar, >98\%), hexadecane (Sigma Aldrich, 99\%), olive oil (Sigma Aldrich, highly refined, low acidity), cetyltrimethylammonium chloride (CTMA-Cl, Acros Organics, 99\%), Lutensol AT50 (BASF), dexamethasone (DXM, Sigma Aldrich, $\geq 98 \%$ ), and sucrose (Sigma Aldrich, $\geq 99.5 \%$ ) were used as received. Amine-reactive fluorescent dyes Cyanine5 NHS ester (Cy5-NHS) and Cyanine7.5 NHS ester (Cy7.5-NHS) were purchased from Lumiprobe $\mathrm{GmbH}$, Germany. Human citrate plasma was obtained from the Department of Transfusion Medicine Mainz from ten healthy donors, pooled and stored at $-80{ }^{\circ} \mathrm{C}$. Prior to use, human plasma was centrifuged for $30 \mathrm{~min}$ at $20000 \mathrm{~g}\left(4^{\circ} \mathrm{C}\right)$ to remove aggregated proteins. Oleic acid capped iron oxide nanoparticles $\left(\mathrm{Fe}_{3} \mathrm{O}_{4}\right.$ NPs) were synthesized according to a standard co-precipitation protocol. ${ }^{83}$

\section{Synthesis of $\mathrm{SiO}_{2} \mathrm{NCs}$}

$\mathrm{SiO}_{2} \mathrm{NCs}$ were synthesized in an oil-in-water miniemulsion by using the surface of oil nanodroplets as template for the hydrolysis and condensation of alkoxysilanes. Specifically, $2.0 \mathrm{~g}$ (9.6 mmol) of TEOS was first mixed with $125 \mathrm{mg}$ of hexadecane and $1 \mathrm{~g}$ of olive oil to form the oil phase. For cargo loading, various amounts of DXM or iron oxide nanoparticles were first dissolved in olive oil. In the second step, $30 \mathrm{~mL}$ of $0.77 \mathrm{mg} \mathrm{mL}^{-1}$ aqueous solution of CTMA-Cl was poured into the oil mixture under stirring. After a pre-emulsification step by stirring at $1000 \mathrm{rpm}$ for $1 \mathrm{~h}$, the obtained emulsion was sonicated by using a Branson $450 \mathrm{~W}$ sonifier with a $1 / 2$ " tip at $70 \%$ amplitude for $180 \mathrm{~s}$ (30 s of sonication, $10 \mathrm{~s}$ of pause) with ice cooling. The resulting miniemulsion was stirred at $1000 \mathrm{rpm}$ for $12 \mathrm{~h}$ at room temperature to obtain an aqueous dispersion of $\mathrm{SiO}_{2}$ NCs. For the fluorescent labeling of $\mathrm{SiO}_{2}$ NCs, Cy5-NHS or Cy7.5-NHS was first coupled with APTES at a molar ratio of $1: 1.1$ to obtain fluorescently labeled silica precursors. The APTES-Cy5/7.5 conjugates were then mixed with TEOS as the silica source. The molar ratio of Cy5 with TEOS was $1: 14000$. For in vivo experiments, the molar ratio of Cy7.5 to TEOS was set as $1: 14000,1: 7000$, and $1: 3500$ for samples $\mathrm{SiO}_{2} \mathrm{NC}-\mathrm{Cy} 7.5$, NC-2 $\times$ Cy7.5, and NC-4 $\times$ Cy7.5, respectively.

\section{PEGylation of $\mathrm{SiO}_{2} \mathrm{NCs}$ and encapsulation efficiency of DXM}

$\mathrm{SiO}_{2}$ NCs were PEGylated by replacing the templating surfactant CTMA-Cl by the nonionic surfactant Lutensol AT50. PEGylated nanocapsules were denoted as $\mathrm{SiO}_{2}$ NC-PEG. Specifically, $35 \mathrm{mg}$ of Lutensol AT50 was added to $2 \mathrm{~mL}$ of $\mathrm{SiO}_{2} \mathrm{NCs}$ dispersion. The dispersion was stirred at $1000 \mathrm{rpm}$ for $2 \mathrm{~h}$ and then dialyzed against water with a dialysis tube with MWCO of $1000 \mathrm{~g} \mathrm{~mol}{ }^{-1}$. In this case, CTMA-Cl $\left(M_{\mathrm{w}}=\right.$ $320 \mathrm{~g} \mathrm{~mol}^{-1}$ ) could diffuse through the dialysis membrane into the aqueous dialysis medium while Lutensol AT50 $\left(M_{\mathrm{w}}=\right.$ $2460 \mathrm{~g} \mathrm{~mol}^{-1}$ ) was kept inside. Dialysis media were changed three times per day until no DXM and CTMA-Cl were detected in the media by UV-Vis spectroscopy and HPLC, respectively. Encapsulation efficiency of DXM in NCs was expressed as the percentage of encapsulated DXM with respect to the initial amount of DXM. The calibration curve for the determination of DXM in water is shown in Fig. S5. $\dagger$ Afterwards, the dialyzed dispersion was centrifuged at $10 \mathrm{k} \mathrm{rpm}$ to remove the excess of Lutensol AT50. The pellet was redispersed in water and the dispersion was stirred at $1000 \mathrm{rpm}$ for $24 \mathrm{~h}$.

\section{Protein corona analysis}

Protein corona preparation. Nanocapsules with a total surface area of $0.05 \mathrm{~m}^{2}$ were incubated in $1 \mathrm{~mL}$ of human citrate plasma for $1 \mathrm{~h}$ at $37^{\circ} \mathrm{C}$ under constant agitation (300 $\mathrm{rpm}) .{ }^{74,84}$ Protein coated nanocapsules were isolated via centrifugation $\left(20000 \mathrm{~g}, 1 \mathrm{~h}, 4^{\circ} \mathrm{C}\right)$ and redispersed in PBS $(1 \mathrm{~mL})$. To remove loosely bound and unbound proteins, this purification procedure was repeated three times. Before the final washing step, the dispersion was transferred into a new Eppendorf-tube. After the last centrifugation step, the nanocapsule pellets were resuspended in a solution containing $2 \mathrm{wt} \%$ SDS and $62.5 \mathrm{mM}$ Tris ${ }^{*} \mathrm{HCl}$. The suspension was incubated at $95{ }^{\circ} \mathrm{C}$ for $5 \mathrm{~min}$ to detach the corona proteins. The sample was then centrifuged $\left(20000 g, 1 \mathrm{~h}, 4{ }^{\circ} \mathrm{C}\right)$ and the supernatant was taken for protein corona analysis.

Protein quantification. Protein content of the corona was determined via Pierce $660 \mathrm{~nm}$ protein Assay (Thermo Scientific) using bovine serum albumin as standard. The absorption was measured at $660 \mathrm{~nm}$ with a Tecan infinite M1000 plate reader.

Liquid chromatography-mass spectrometry (LC-MS) analysis. Proteomic analysis was carried out as previously described. ${ }^{84,85}$ Briefly, SDS was removed from the protein sample via Pierce Detergent Removal Spin Columns (Thermo Fisher). Further, proteins were precipitated using ProteoExtract protein precipitation kit (CalBioChem) overnight. Afterwards, the protein pellets were isolated via centrifugation (14000g, $10 \mathrm{~min}$ ) and resuspended with RapiGest SF (Waters) in ammonium bicarbonate $(50 \mathrm{mM})$. The protein solution was reduced with dithiothreitol (Sigma) at a concentration of $5 \mathrm{mM}$ for $45 \mathrm{~min}$ at $56^{\circ} \mathrm{C}$ and alkylated with $15 \mathrm{mM}$ idoacetoamide (Sigma) for $1 \mathrm{~h}$ in the dark. Tryptic digestion (protein:trypsin ratio 50:1) was carried out for $18 \mathrm{~h}$ at $37^{\circ} \mathrm{C}$. Afterwards, the reaction was quenched with $2 \mu \mathrm{L}$ hydrochloric acid (Sigma). 
Tryptic peptides were diluted with $0.1 \%$ formic acid spiked with 50 fmol $\mu \mathrm{L}^{-1} \mathrm{Hi} 3 \mathrm{E}$. coli (Waters) for absolute protein quantification. The peptide solution was injected into a nanoACQUITY UPLC system coupled to a Synapt G2-Si mass spectrometer. The system was operated in resolution mode, with a NanoLockSpray source in positive ion mode. Data-independent acquisition $\left(\mathrm{MS}^{\mathrm{E}}\right)$ experiments were performed and data was analyzed with MassLynx 4.1.

Proteins were identified with Progenesis GI (2.0) using a reviewed human database downloaded from Uniprot. For analysis, the following criteria were chosen: max. protein mass $600 \mathrm{kDa}$, one missed cleavage, fixed modifications for carbamidomethyl and cysteine, variable oxidation for methionine, and a false discovery rate of $4 \%$. Peptide identification requires three identified fragments and for proteins identification five identified fragments and two peptides are needed. Based on the TOP3/Hi3 quantification the amount of each protein in fmol is provided. ${ }^{86}$ All identified proteins are summarized in a separate Excel file as ESI. $\dagger$

\section{TEM analysis}

Sapphire disks ( $3 \mathrm{~mm}$; M. Wohlwend $\mathrm{GmbH}$ ) were pre-coated with a $10 \mathrm{~nm}$-thick carbon layer using an EM MED020 instrument (Leica). The coated sapphire disks were dried and sterilized in an oven at $120{ }^{\circ} \mathrm{C}$ overnight before use. HeLa cells were seeded onto sapphire disks in 12-well plates overnight for cell attachment. $\mathrm{SiO}_{2} \mathrm{NCs}$ (loaded with $\mathrm{Fe}_{3} \mathrm{O}_{4} \mathrm{NPs}$ ) were incubated with HeLa Cells at $75 \mu \mathrm{g} \mathrm{m}^{-1}$ for $2 \mathrm{~h}, 10 \mathrm{~h}$, and overnight in a humidified incubator at $37{ }^{\circ} \mathrm{C}$ and $5 \% \mathrm{CO}_{2}$. After the incubation, each sapphire disk was collected from the 12-well plates and slightly immersed into 1-hexadecene before placing them between two aluminum plates $(3 \mathrm{~mm}$, Plano). This "sandwich" structure was placed into a specimen holder for high pressure freezing in a Wohlwend HPF Compact 01 high pressure freezer with a pressure of 2100 bar for 2-3 s. The specimen holder was withdrawn from the freezer and immersed into liquid nitrogen to release the sample. The frozen sample was then labeled and stored in a container filled with liquid nitrogen. Subsequently, freeze substitution of the sample was carried out in a $0.5 \mathrm{ml}$ Eppendorf tube using an AFS2 automated freeze substitution device (Leica). Each tube contained $1 \mathrm{ml}$ of freeze substitution solution, consisting of $0.2 \mathrm{wt} / \mathrm{vol} \%$ osmium tetroxide, $0.1 \mathrm{wt} / \mathrm{vol} \%$ uranyl acetate, and $5 \%$ distilled water in acetone. The tubes were firstly kept at $-90{ }^{\circ} \mathrm{C}$ and slowly warmed up to $0{ }^{\circ} \mathrm{C}$ in $24 \mathrm{~h}$. After keeping at room temperature for $1 \mathrm{~h}$, the substitution solution was removed and the samples were washed 3 times with acetone. Each sample was infiltrated in an ascending epoxy resin series ( $30 \%, 50 \%$, and $75 \%$ in acetone) for $1 \mathrm{~h}$ before finally infiltration in $100 \%$ epoxy resin overnight. Finally, each sample was transferred into a new Eppendorf tube containing freshly prepared pure epoxy resin for polymerization at $60{ }^{\circ} \mathrm{C}$ for $24 \mathrm{~h}$. After polymerization, sample blocks were kept at room temperature until their sectioning. Sample blocks for each time point were trimmed and sectioned into $100 \mathrm{~nm}$ sections by a $45^{\circ}$ diamond knife (Diatome) in EM UC6 ultramicrotome
(Leica). Sections were then carefully placed onto 300-mesh copper grid for standard bright-field, electron energy loss spectroscopy (EELS), and energy dispersive X-ray spectroscopy (EDX) analysis in Tecnai F20 $200 \mathrm{kV}$ transmission electron microscope (TEM) (FEI). Bright-field TEM micrographs were obtained with a Gatan US1000 2k CCD camera. EDX images were collected with an EDAX detector.

\section{Isolation of non-parenchymal liver cells and stimulation with $\mathrm{SiO}_{2} \mathrm{NCs}$}

Six to eight-week old female C57BL/6J mice were obtained from Janvier (Le Genest-Saint-Isle, France). All mice were kept under a $12 \mathrm{~h}$ dark/12 h light cycle (with food and water supply ad libitum) in the animal facility of the Translational Animal Research Center, University Medical Center Mainz, Germany. The animals were treated in accordance with NIH publications entitled "Principles for Use of Animals" and "Guide for the Care and Use of Laboratory Animals". All protocols have been approved by the local Animal Care and Use Committee ("Landesuntersuchungsamt Rheinland-Pfalz"). The murine non-parenchymal liver cells (NPCs) were isolated from livers as previously reported. ${ }^{87,88}$ Briefly, mice were anesthetized with Ketamin/Rompun and livers were perfused with cold $20 \mathrm{ml}$ $\mathrm{Ca}^{2+}$ - and $\mathrm{Mg}^{2+}$-free Hank's Balanced Salt Solution (HBSS; Sigma-Aldrich, St Louis, USA) containing $100 \mathrm{U} \mathrm{l}^{-1}$ collagenase A (Roche Diagnostics GmbH, Mannheim, Germany), 5\% heatinactivated fetal calf serum (FCS, GE Healthcare Life Sciences, Chalfont St Giles, UK), and $10 \mu \mathrm{g} \mathrm{m}{ }^{-1}$ DNase I (Applichem, Darmstadt, Germany). Following dissection, the livers were incubated for $15 \mathrm{~min}$ at $37^{\circ} \mathrm{C}$ and grinded through a $70 \mu \mathrm{m}$ cell strainer to generate single cell suspensions. Hepatocytes were pelleted and discarded after centrifugation for $15 \mathrm{~min}$ at $4{ }^{\circ} \mathrm{C}$ and $30 \mathrm{~g}$. The non-parenchymal cell fraction remaining in the supernatant was further purified by centrifugation at $300 g$, resuspended in Histodenz solution in HBSS to reach a final concentration of $20 \%$ and overlaid with HBSS, followed by centrifugation at $1500 \mathrm{~g}$ for $20 \mathrm{~min}$. NPCs were collected at the Histodenz/HBSS interface and washed with RPMI 1640 medium containing 5\% FCS and 1\% penicillin/streptomycin. The cell suspension was then cultured in HEPESbuffered RPMI 1640 medium containing 10\% FCS, 1\% penicillin/streptomycin, $1 \mathrm{mM}$ L-glutamine, 1\% essential and nonessential amino acids, $1 \mathrm{mM}$ sodium pyruvate, $50 \mathrm{nM}$ $\beta$-mercaptoethanol, and with or without $2.5 \mu \mathrm{g} \mathrm{ml} \mathrm{m}^{-1}$ lipopolysaccharide (LPS) at concentration of $10^{6} \mathrm{NPCs} \mathrm{ml}^{-1}$. Different formulations of $\mathrm{SiO}_{2}$ NCs containing cy5 or DXM as well as soluble DXM-phosphate were added at different concentrations and incubated for $24 \mathrm{~h}$ as indicated.

\section{Toxicity and uptake of $\mathrm{SiO}_{2} \mathrm{NCs}$ and cytokine secretion}

Toxicity and uptake of $\mathrm{SiO}_{2}$ NC by NPCs was analyzed by propidium iodide (PI, BD Pharmingen) staining ( $5 \mu \mathrm{l}$ per sample) and subsequent flow cytometric quantification (BD LSR II) of PI and NC positive cells. Interleukin-6 (IL-6) levels in cell culture supernatants were analyzed using an enzyme-linked 
immunosorbent assay kit (ThermoFisher) according to manufacturer's instructions.

\section{In vivo imaging of $\mathrm{SiO}_{2} \mathrm{NCs}$}

C57BL6/Albino mice were depilated at the abdominal and thoracic zone and the corresponding dorsal areas $400 \mu \mathrm{g}$ of $\mathrm{SiO}_{2}$ NCs labeled with increasing concentrations of Cy7.5 were injected intravenously and mice were analyzed $30 \mathrm{~min}$ after injection using the IVIS SpectrumCT imager (PerkinEllmer, Waltham, USA) and the Living Image Software 4.5. Subsequently, mice were sacrificed and the organs (liver, spleen, kidneys, lungs, heart) were isolated and analyzed again.

\section{Characterization}

Hydrodynamic diameters of $\mathrm{SiO}_{2}$ NCs were measured by dynamic light scattering (DLS) with a Nicomp particle sizer (Model 380, PSS, Santa Barbara, CA) at a fixed scattering angle of $90^{\circ}$. The morphology of nanocapsules was examined with a Gemini 1530 (Carl Zeiss AG, Oberkochem, Germany) scanning electron microscope (SEM) operating at $0.35 \mathrm{kV}$ and a Jeol 1400 (Jeol Ltd, Tokyo, Japan) transmission electron microscope operating at an accelerating voltage of $120 \mathrm{kV}$. SEM and TEM samples of nanocapsules were prepared by casting the diluted dispersions on silicon wafers and carbon layer-coated copper grids, respectively. The capsule dispersions were dialyzed against Milli-Q water for 3 days to remove the surfactant. The dialyzed dispersions were then freeze-dried for $48 \mathrm{~h}$ and degassed at $70{ }^{\circ} \mathrm{C}$ under high vacuum for at least $12 \mathrm{~h}$ before measurements. The specific surface area was calculated using the Brunauer-Emmett-Teller (BET) equation based on data points obtained from $0<P / P_{0}<0.25$. Zeta potential measurements were performed in $10^{-3} \mathrm{M}$ potassium chloride solution at $\mathrm{pH} 6.8$ and $25{ }^{\circ} \mathrm{C}$ with a Malvern Zeta sizer (Malvern Instruments, UK). Solid content of the capsule dispersion was measured gravimetrically. Quantitative ${ }^{29}$ Si MAS-NMR spectra were recorded with a Bruker Avance II spectrometer according to our previous work. ${ }^{89}$ Numbers of CTMA-Cl and Lutensol AT50 molecules per $\mathrm{NC}$ and per $\mathrm{nm}^{2}$ surface were calculated by dividing the number of surfactant molecules by the number and total surface area of NCs, respectively. The number of NCs in dispersion was determined based on the solid content of the dispersion and the mass of single NC. Multiangle DLS measurements were performed using an instrument from ALV (Langen, Germany) with an electronically controlled goniometer and an ALV-5000 multiple $\tau$ full-digital correlator with 320 channels for measurements in the range between $10^{-7} \mathrm{~s}$ and $10^{3} \mathrm{~s}$. The source of light was a helium-neon laser of the Type 1145 P from JDS Uniphase (Milpitas, USA) with $632.8 \mathrm{~nm}$ wavelength and $25 \mathrm{mV}$ output power. Before the measurements, PBS or undiluted human plasma was filtered through Millex-LCR filters (Merck Millipore, Billerica, USA) with $450 \mathrm{~nm}$ pore size into quartz cuvettes with an inner radius of $9 \mathrm{~mm}$ for light scattering from Hellma (Müllheim, Germany). After filtration of the eluent, $2 \mu \mathrm{L}$ of the $\mathrm{NC}$ dispersions (30 $\mathrm{mg} \mathrm{mL}^{-1}$ ) were added. Prior to use, the quartz cuvettes were cleaned with acetone using a Thurmond apparatus. ${ }^{90}$ For data analysis, a robust multicomponent fit method reported by Rausch et al. ${ }^{70}$ was used. UV-Vis absorption spectra of DXM solution were recorded with a PerkinElmer Lambda 25 UV-Vis spectrometer. Gradient centrifugation experiments were performed at $4{ }^{\circ} \mathrm{C}$ and $5000 \mathrm{rpm}$ for $3 \mathrm{~h}$ in a Rotixa 50RS ultracentrifuge, Hettich. Sucrose solutions with densities ranging between 1.00 and $1.30 \mathrm{~g} \mathrm{~cm}^{-3}$ were used.

\section{Conflicts of interest}

There are no conflicts to declare.

\section{Acknowledgements}

We acknowledge Stefan Schuhmacher for scheme drawing. Open Access funding provided by the Max Planck Society. SJ, DC, and KL are grateful to the Max Planck-VISTEC Partner Laboratory for Sustainable Materials. MM acknowledges the fellowship of the DAAD for a training period in the frame of a PhD work at IIBYT (CONICET-Universidad Nacional de Córdoba) as a doctoral fellow from CONICET, Argentina.

\section{References}

1 G. Mieli-Vergani and D. Vergani, Best Pract. Res., Clin. Gastroenterol., 2011, 25, 783-795.

2 L. W. Doyle, R. A. Ehrenkranz and H. L. Halliday, Neonatology, 2010, 98, 217-224.

3 C.-M. Ho, H.-L. Wu, S.-T. Ho and J.-J. Wang, Acta Anaesthesiol. Taiwan., 2011, 49, 100-104.

4 V. Krishnan, X. Xu, S. P. Barwe, X. Yang, K. Czymmek, S. A. Waldman, R. W. Mason, X. Jia and A. K. Rajasekaran, Mol. Pharm., 2013, 10, 2199-2210.

5 J. Urbańska, A. Karewicz and M. Nowakowska, J. Life Sci., 2014, 96, 1-6.

6 N. J. London, A. Chiang and J. A. Haller, Adv. Ther., 2011, 28, 351-366.

7 R. L. Meyers, L. S. Book, M. A. O'Gorman, W. D. Jackson, R. E. Black, D. G. Johnson and M. E. Matlak, J. Pediatr. Surg., 2003, 38, 406-411.

8 M. Hegeman, P. Cobelens, J. Kamps, M. Hennus, N. Jansen, M. Schultz, A. Van Vught, G. Molema and C. Heijnen, Br. J. Pharmacol., 2011, 163, 1048-1058.

9 B. N. Melgert, P. Olinga, J. M. Van Der Laan, B. Weert, J. Cho, D. Schuppan, G. M. Groothuis, D. K. Meijer and K. Poelstra, Hepatology, 2001, 34, 719-728.

10 J. Napp, M. A. Markus, J. G. Heck, C. Dullin, W. Möbius, D. Gorpas, C. Feldmann and F. Alves, Theranostics, 2018, 8, 6367.

11 L. Michelle, L. C. Peter and K. Hisataka, Curr. Top. Med. Chem., 2008, 8, 1180-1186.

12 M. D. Joshi and R. Müller, Eur. J. Pharm. Biopharm., 2009, 71, 161-172. 
13 M.-T. Wang, Y. Jin, Y.-X. Yang, C.-Y. Zhao, H.-Y. Yang, X.-F. Xu, X. Qin, Z.-D. Wang, Z.-R. Zhang and Y.-L. Jian, Int. J. Nanomed., 2010, 5, 487.

14 K. Poelstra, J. Prakash and L. Beljaars, J. Controlled Release, 2012, 161, 188-197.

15 N.-N. Li, J. Lin, D. Gao and L.-M. Zhang, J. Colloid Interface Sci., 2014, 417, 301-309.

16 D. Wang, S. C. Miller, X.-M. Liu, B. Anderson, X. S. Wang and S. R. Goldring, Arthritis Res. Ther., 2007, 9, R2.

17 X.-M. Liu, L.-D. Quan, J. Tian, Y. Alnouti, K. Fu, G. M. Thiele and D. Wang, Pharm. Res., 2008, 25, 29102919.

18 K. Ren, A. Dusad, F. Yuan, H. Yuan, P. E. Purdue, E. V. Fehringer, K. L. Garvin, S. R. Goldring and D. Wang, J. Controlled Release, 2014, 175, 1-9.

19 H. Krakovičová, T. Etrych and K. Ulbrich, Eur. J. Pharm. Sci., 2009, 37, 405-412.

20 M. D. Howard, A. Ponta, A. Eckman, M. Jay and Y. Bae, Pharm. Res., 2011, 28, 2435-2446.

21 A. G. Bajpayee, M. A. Quadir, P. T. Hammond and A. J. Grodzinsky, Osteoarthrotic Cartilage, 2016, 24, 71-81.

22 D. Funk, H.-H. Schrenk and E. Frei, J. Drug Targeting, 2011, 19, 434-445.

23 C. Wang, H. Hou, K. Nan, M. J. Sailor, W. R. Freeman and L. Cheng, Exp. Eye Res., 2014, 129, 74-82.

24 Y. Zhao, C. Wei, X. Chen, J. Liu, Q. Yu, Y. Liu and J. Liu, ACS Appl. Mater. Interfaces, 2019, 11, 11587-11601.

25 N.-N. Li, J. Lin, D. Gao and L.-M. Zhang, J. Colloid Interface Sci., 2014, 417, 301-309.

26 T. Numpilai, T. Witoon, M. Chareonpanich and J. Limtrakul, Appl. Surf. Sci., 2017, 396, 504-514.

27 S. L. Timofeevski, E. F. Panarin, O. L. Vinogradov and M. V. Nezhentsev, Pharm. Res., 1996, 13, 476-480.

28 N. Butoescu, C. A. Seemayer, M. Foti, O. Jordan and E. Doelker, Biomaterials, 2009, 30, 1772-1780.

29 J. S. Park, H. N. Yang, S. Y. Jeon, D. G. Woo, M. S. Kim and K.-H. Park, Biomaterials, 2012, 33, 8600-8612.

30 L. Zhang, Y. Li, C. Zhang, Y. Wang and C. Song, Int. J. Nanomed., 2009, 4, 175.

31 C. Song, V. Labhasetwar, H. Murphy, X. Qu, W. Humphrey, R. Shebuski and R. Levy, J. Controlled Release, 1997, 43, 197-212.

32 C. Fornaguera, M. Llinàs, C. Solans and G. Calderó, Colloids Surf., B, 2015, 125, 58-64.

33 C. Gómez-Gaete, E. Fattal, L. Silva, M. Besnard and N. Tsapis, J. Controlled Release, 2008, 128, 41-49.

34 J. Cao, M. Naeem, J.-K. Noh, E. H. Lee and J.-W. Yoo, Macromol. Res., 2015, 23, 485-492.

35 J. Panyam, D. Williams, A. Dash, D. Leslie-Pelecky and V. Labhasetwar, J. Pharm. Sci., 2004, 93, 1804-1814.

36 D.-H. Kim and D. C. Martin, Biomaterials, 2006, 27, 30313037.

37 C. Gómez-Gaete, N. Tsapis, M. Besnard, A. Bochot and E. Fattal, Int. J. Pharm., 2007, 331, 153-159.

38 C. Ruy, S. Silvia, J. F. Rodrigo, B. M. Cecília, I. Barcellos and J. A. Funck, Acta Farm. Bonaerense, 2003, 22, 11-15.
39 N. Döge, S. Hönzke, F. Schumacher, B. Balzus, M. Colombo, S. Hadam, F. Rancan, U. Blume-Peytavi, M. Schäfer-Korting and A. Schindler, J. Controlled Release, 2016, 242, 25-34.

40 M. Argenziano, C. Dianzani, B. Ferrara, S. Swaminathan, A. Manfredi, E. Ranucci, R. Cavalli and P. Ferruti, Gels, 2017, 3, 22.

41 O. F. Turkoglu, H. Eroglu, O. Okutan, E. Burul, M. F. Sargon, N. Özer, L. Öner and E. Beskonaklı, Surg. Neurol., 2005, 64, S11-S16.

42 M. Ryu, T. Nakazawa, T. Akagi, T. Tanaka, R. Watanabe, M. Yasuda, N. Himori, K. Maruyama, T. Yamashita and T. Abe, J. Controlled Release, 2011, 151, 65-73.

43 L. Serpe, R. Canaparo, M. Daperno, R. Sostegni, G. Martinasso, E. Muntoni, L. Ippolito, N. Vivenza, A. Pera and M. Eandi, Eur. J. Pharm. Sci., 2010, 39, 428-436.

44 R. Beck, A. Pohlmann, C. Hoffmeister, M. Gallas, E. Collnot, U. Schaefer, S. Guterres and C. Lehr, Eur. J. Pharm. Biopharm., 2007, 67, 18-30.

45 F. Rafie, Y. Javadzadeh, A. R. Javadzadeh, L. A. Ghavidel, B. Jafari, M. Moogooee and S. Davaran, Curr. Eye Res., 2010, 35, 1081-1089.

46 J. Schmidt, J. M. Metselaar, M. H. M. Wauben, K. V. Toyka, G. Storm and R. Gold, Brain, 2003, 126, 1895-1904.

47 J. M. Metselaar, M. H. M. Wauben, J. P. A. WagenaarHilbers, O. C. Boerman and G. Storm, Arthritis Rheum., 2003, 48, 2059-2066.

48 J. M. Metselaar, W. B. van den Berg, A. E. M. Holthuysen, M. H. M. Wauben, G. Storm and P. L. E. M. van Lent, Ann. Rheum. Dis., 2004, 63, 348-353.

49 Y. Avnir, R. Ulmansky, V. Wasserman, S. Even-Chen, M. Broyer, Y. Barenholz and Y. Naparstek, Arthritis Rheum., 2008, 58, 119-129.

50 X. Luo, C. Matranga, S. Tan, N. Alba and X. T. Cui, Biomaterials, 2011, 32, 6316-6323.

51 Q. Pan, Q. Xu, N. J. Boylan, N. W. Lamb, D. G. Emmert, J.-C. Yang, L. Tang, T. Heflin, S. Alwadani and C. G. Eberhart, J. Controlled Release, 2015, 201, 32-40.

52 N. J. Kenyon, J. M. Bratt, J. Lee, J. Luo, L. M. Franzi, A. A. Zeki and K. S. Lam, PLoS One, 2013, 8, e77730.

53 A. Lee, C. De Mei, M. Fereira, R. Marotta, H. Y. Yoon, K. Kim, I. C. Kwon and P. Decuzzi, Theranostics, 2017, 7, 3653.

54 R. B. Friedrich, M. C. Fontana, R. C. R. Beck, A. R. Pohlmann and S. S. Guterres, Quim. Nova, 2008, 31, 1131-1136.

55 X.-M. Liu, L.-D. Quan, J. Tian, F. C. Laquer, P. Ciborowski and D. Wang, Biomacromolecules, 2010, 11, 2621-2628.

56 N. Butoescu, O. Jordan, A. Petri-Fink, H. Hofmann and E. Doelker, J. Microencapsulation, 2008, 25, 339-350.

57 M. Bartneck, K. M. Scheyda, K. T. Warzecha, L. Y. Rizzo, K. Hittatiya, T. Luedde, G. Storm, C. Trautwein, T. Lammers and F. Tacke, Biomaterials, 2015, 37, 367-382.

58 I. Lynch, A. Salvati and K. A. Dawson, Nat. Nanotechnol., 2009, 4, 546.

59 C. D. Walkey and W. C. W. Chan, Chem. Soc. Rev., 2012, 41, 2780-2799. 
60 R. M. Pearson, V. V. Juettner and S. Hong, Front. Chem., 2014, 2, 108.

61 A. Maity, R. Belgamwar and V. Polshettiwar, Nat. Protoc., 2019, 14, 2177-2204.

62 A. P. Philipse, M. P. Van Bruggen and C. Pathmamanoharan, Langmuir, 1994, 10, 92-99.

63 D. Wibowo, Y. Hui, A. P. J. Middelberg and C.-X. Zhao, Adv. Colloid Interface Sci., 2016, 236, 83-100.

64 I.-Y. Kim, E. Joachim, H. Choi and K. Kim, Nanomedicine, 2015, 11, 1407-1416.

65 Q. Wu, Y. Hou, G. Han, X. Liu, X. Tang, H. Li, X. Song and G. Zhang, Nanomedicine, 2017, 12, 2699-2711.

66 S. Behzadi, V. Serpooshan, W. Tao, M. A. Hamaly, M. Y. Alkawareek, E. C. Dreaden, D. Brown, A. M. Alkilany, O. C. Farokhzad and M. Mahmoudi, Chem. Soc. Rev., 2017, 46, 4218-4244.

67 Q. He, J. Shi, M. Zhu, Y. Chen and F. Chen, Microporous Mesoporous Mater., 2010, 131, 314-320.

68 V. Cauda, A. Schlossbauer and T. Bein, Microporous Mesoporous Mater., 2010, 132, 60-71.

69 K. Mohr, M. Sommer, G. Baier, S. Schöttler, P. Okwieka, S. Tenzer, K. Landfester, V. Mailänder, M. Schmidt and R. G. Meyer, J. Nanomed. Nanotechnol., 2014, 5, 193.

70 K. Rausch, A. Reuter, K. Fischer and M. Schmidt, Biomacromolecules, 2010, 11, 2836-2839.

71 D. E. Owens III and N. A. Peppas, Int. J. Pharm., 2006, 307, 93-102.

72 S. Salmaso and P. Caliceti, J. Drug Delivery, 2013, 2013.

73 J. Müller, K. N. Bauer, D. Prozeller, J. Simon, V. Mailänder, F. R. Wurm, S. Winzen and K. Landfester, Biomaterials, 2017, 115, 1-8.

74 S. Schöttler, G. Becker, S. Winzen, T. Steinbach, K. Mohr, K. Landfester, V. Mailänder and F. R. Wurm, Nat. Nanotechnol., 2016, 11, 372-377.

75 S. Schöttler, K. Landfester and V. Mailänder, Angew. Chem., Int. Ed., 2016, 55, 8806-8815.
76 M. Aoyama, K. Hata, K. Higashisaka, K. Nagano, Y. Yoshioka and Y. Tsutsumi, Biochem. Biophys. Res. Commun., 2016, 480, 690-695.

77 J. Simon, J. Müller, A. Ghazaryan, S. Morsbach, V. Mailänder and K. Landfester, Nanoscale, 2018, 10, 21096-21105.

78 N. Bertrand, P. Grenier, M. Mahmoudi, E. M. Lima, E. A. Appel, F. Dormont, J.-M. Lim, R. Karnik, R. Langer and O. C. Farokhzad, Nat. Commun., 2017, 8, 777.

79 M. Kokkinopoulou, J. Simon, K. Landfester, V. Mailänder and I. Lieberwirth, Nanoscale, 2017, 9, 8858-8870.

80 R. Cukalevski, S. A. Ferreira, C. J. Dunning, T. Berggård and T. Cedervall, Nano Res., 2015, 8, 2733-2743.

81 S. Behzadi, V. Serpooshan, R. Sakhtianchi, B. Müller, K. Landfester, D. Crespy and M. Mahmoudi, Colloids Surf., B, 2014, 123, 143-149.

82 B. Saberi, A. S. Dadabhai, Y.-Y. Jang, A. Gurakar and E. Mezey, J. Clin. Transl. Hepatol., 2016, 4, 113.

83 M. B. Bannwarth, S. W. Kazer, S. Ulrich, G. Glasser, D. Crespy and K. Landfester, Angew. Chem., Int. Ed., 2013, 52, 10107-10111.

84 M. Kokkinopoulou, J. Simon, K. Landfester, V. Mailänder and I. Lieberwirth, Nanoscale, 2017, 9, 8858-8870.

85 J. Simon, T. Wolf, K. Klein, K. Landfester, V. Mailänder and F. R. Wurm, Angew. Chem., Int. Ed., 2018, 57, 5548-5553.

86 J. C. Silva, M. V. Gorenstein, G.-Z. Li, J. P. Vissers and S. J. Geromanos, Mol. Cell. Proteomics, 2006, 5, 144-156.

87 S. Gehring, E. M. Dickson, M. E. San Martin, N. van Rooijen, E. F. Papa, M. W. Harty, T. F. Tracy Jr. and S. H. Gregory, Gastroenterology, 2006, 130, 810-822.

88 M. Fichter, G. Baier, M. Dedters, L. Pretsch, A. PietrzakNguyen, K. Landfester and S. Gehring, Nanomedicine, 2013, 9, 1223-1234.

89 J. Fickert, P. Rupper, R. Graf, K. Landfester and D. Crespy, J. Mater. Chem., 2012, 22, 2286-2291.

90 C. D. Thurmond, J. Polym. Sci., 1952, 8, 607-609. 